\title{
Hubungan Aktivitas Fisik Dan Asupan Gizi Dengan Status Gizi Lebih Pada Anak Usia Sekolah Dasar Di Sdn Ketabang 1 Kota Surabaya Tahun 2017
}

\author{
Relationship between Physical Activity, Nutrition Intake and Overweight \\ Status among Elementary School Student in SDN Ketabang 1 Surabaya 2017
}

Nadya Dayinta N Ermona ${ }^{*}$, Bambang Wirjatmadi ${ }^{1}$

\begin{abstract}
ABSTRAK
Latar Belakang : Masalah gizi lebih yang terjadi di Indonesia masih tergolong tinggi dengan prevalensi 18,8\%. Berat badan lebih (overweight) dan obesitas merupakan kondisi sesorang dimana keabnormalan akumulasi lemak yang berlebih dan dapat menyebabkan gangguan kesehatan. Beberapa faktor yang dapat menyebabkan kegemukan satu diantaranya yaitu pola aktivitas dan pola makan.

Tujuan : tujuan dalam penelitian ini adalah untuk menganalisis hubungan antara aktivitas fisik dan asupan gizi dengan status gizi pada anak sekolah usia 8-12 tahun.

Metode : penelitian ini dilaksanakan dengan metode observasional analitik menggunakan desain cross-sectional pada 88 sampel dan dipilih dengan menggunakan simple random sampling. Pengumpulan data terdiri dari pengukuran berat badan, pengukuran tinggi badan, recall $2 \times 24$ jam untuk mengetahui tingkat konsumsi dan wawancara dengan kuesioner Physical Activity Questionnaire for Children (PAQ-C).

Hasil : penelitian ini menunjukkan bahwa terdapat hubungan antara aktivitas fisik, tingkat asupan energi, tingkat asupan protein, tingkat asupan karbohidrat dan tingkat asupan lemak dengan status gizi lebih anak sekolah $(p<0,05)$.

Kesimpulan : aktivitas fisik yang rendah dan asupan gizi merupakan faktor yang dapat menyebabkan masalah gizi lebih pada anak.
\end{abstract}

Kata Kunci: gizi lebih, aktivitas fisik, asupan gizi 


\title{
ABSTRACT
}

Background: overnutrition problem in children of school age in Indonesia classified as high with the prevalence was $18.8 \%$. Overweight and obesity is an abnormal condition of fat accumulation which caused health problem. There is some of factor caused overweight and obesity are physical activity and nutrition intake.

Objective: this study was an observasional analytic using cross sectional design, 88 samples 8-12 years were selected using simple ramdom sampling technique. Data were collected by measuring weight, height, $2 \times 24$ hours recall for food intake level, and interview using Physical Activity Questionnaire for Children (PAQ-C).

Results : the results showed that there was relationship in physical activity, intake of energy, intake of protein, intake of carbohydrate, and intake of fat with overnutrition of elementary student $(p<0.05)$. Conclusion: the low of physical activity and nutrition intake is a factor which can cause overnutrition problem in children.

Keywords: overnutrition, physical activity, nutrition intake

\author{
*Koresponden: \\ nadyachiquitita@gmail.com \\ ${ }^{1}$ Departemen Gizi Kesehatan \\ Fakultas Kesehatan Masyarakat, Universitas Airlangga
}

\section{PENDAHULUAN}

Obesitas merupakan salah satu yang menjadi masalah kesehatan didunia yang dinyatakan oleh WHO sebagai masalah epidemi global sehingga memerlukan penanganan segera ${ }^{1}$. Peningkatan prevalensi kegemukan berdasarkan WHO meningkat selama sepuluh tahun terakhir dari tahun 1990 sampai tahun 2010 yaitu sebesar 2,5\% pada anak dan remaja ${ }^{2}$. Diperkirakan sebanyak 35 juta dari 45 juta anak mengalami kegemukan yang berasal dari negara berkembang ${ }^{3}$.

Indonesia merupakan salah satu negara berkembang yang sedang mengalami masalah gizi ganda. Masalah gizi ganda yang sedang dihadapi Indonesia adalah terjadinya masalah gizi kurang yang belum terselesaikan dan bersamaan pula muncul masalah gizi lebih ${ }^{4}$. Berat badan lebih (overweight) dan obesitas merupakan kondisi sesorang dimana ketidakseimbangan antara jumlah energi yang dikonsumsi dengan yang dibutuhkan oleh tubuh. Kegemukan dan obesitas adalah masalah yang banyak terjadi pada usia dewasa, namun tidak menutup kemungkinan masalah tersebut juga terjadi pada anak-anak usia sekolah ${ }^{4}$.
Kegemukan dan obesitas didefinisikan sebagai kondisi dimana intake kalori seseorang lebih banyak daripada kalori yang digunakan. Masalah gizi lebih yang terjadi pada anak-anak usia sekolah ini merupakan masalah yang serius yang dapat mempengaruhi peningkatan resiko beberapa penyakit kronik baik dinegara maju maupun berkembang. Apabila seorang anak telah mengalami masalah gizi lebih diusia muda maka akan cenderung pula akan terus berlanjut sampai usia dewasa dimana dapat menimbulkan resiko timbulnya penyakit seperti diabetes dan gangguan kardivaskular pada usia muda ${ }^{1}$.

Tren kegemukan di Indonesia berdasarkan Riskesdas dari tahun 2007 sampai tahun 2013 untuk usia 5-12 tahun cenderung mengalami peningkatan. Pada tahun 2007 prevalensi kegemukan untuk usia 5-12 tahun adalah sebesar $6,4 \%$. Angka ini meningkat pada tahun 2010 menjadi prevalensinya adalah 9,2\%. Data Riset Kesehatan Dasar tahun 2013 menunjukkan bahwa prevalensi obesitas untuk kelompok usia 5-12 tahun, 1315 tahun dan 16-18 tahun secara berturutturut adalah $8,8 \% ; 2,5 \%$ dan 1,6\%. Data tersebut menunjukkan bahwa prevalensi 
obesitas lebih banyak terjadi pada anak usia sekolah dasar dibandingkan remaja. Masalah gizi lebih yang terjadi di Indonesia masih tergolong tinggi dengan prevalensi $18,8 \%$ yang terdiri dari 10,8\% berstatus gemuk dan $8,8 \%$ berstatus obesitas ${ }^{5}$.

Provinsi Jawa Timur menempati posisi kedua diantara 15 provinsi lain dengan prevalensi sangat gemuk diatas normal ${ }^{5}$. Kota Surabaya memiliki prevalensi sebesar 8,9\% untuk kejadian kegemukan. Hasil prevalensi nasional di Indonesia menunjukkan berat badan berlebih untuk kelompok usia 6-14 tahun pada laki-laki adalah $9,5 \%$ sedangkan untuk perempuan sebesar $6,4 \%{ }^{6}$.

Sekolah Dasar Negeri Ketabang 1 Kota Surabaya merupakan salah satu sekolah dasar yang terletak di kawasan Surabaya Pusat. Studi pendahuluan telah dilakukan untuk memperoleh data kegemukan dan obesitas pada siswa di sekolah tersebut. Hasil penelitian yang dilakukan adalah screening terhadap 656 siswa dan didapapatkan hasil $3,75 \%$ beresiko tinggi untuk mengalami obesitas sedangkan sisanya sebanyak $14,6 \%$ mengalami obesitas ${ }^{7}$.

Seorang anak yang mengalami kegemukan disebabkan oleh beberapa faktor yang diantaranya adalah faktor fisiologis. Faktor fisiologis ini berasal dari berbagai variabel baik yang bersifat herediter maupun non herediter. Faktor herediter berasal dari faktor keturunan, sedangkan faktor non herediter meliputi pola makan, tingkat asupan gizi, tingkat aktivitas fisik serta kondisi sosial ekonomi ${ }^{8}$. Salah satu faktor penyebab kegemukan adalah faktor gaya hidup dimana semakin berjamurnya toko yang menyediakan makanan cepat saji. Hal ini akan menyebabkan kebiasaan anak untuk mengkonsumsi makanan tersebut ditambah dengan kesibukan orang tua yang tak sempat memperhatikan asupan makanan anaknya. $\mathrm{Hal}$ ini ditambah dengan perkembangan jaman era globalisasi dengan semua semakin canggih yang akan mengurangi kesempatan anak untuk melakukan aktivitas fisik. Kemudahan transportasi, komputer, film, televisi, game, dan makanan cepat saji telah membuat kebiasaan hidup menjadi santai dan malas sehingga menyebabkan kegemukan pada anak?

Kegemukan terjadi jika adanya ketidakseimbangan antara asupan energi dan keluaran energi dalam jangka waktu yang lama sehingga akan ditimbun sebagai lemak yang berlebihan. Kelebihan konsumsi makanan menyebabkan asupan energi yang tinggi sebagai sebab oleh rendahnya aktivitas fisik $^{10}$. Perubahan gaya hidup sejalan dengan peningkatan tingkat kemamkuran yang berdampak pula pada kebiasaan makan. Pola makan bergeser menjadi konsumsi makanan dengan tinggi lemak, gula dan garam dimana makanan tersebut mengabdung sedikit serat dan vitamin. Hal ini akan menyebabkan ketidakseimbangan mutu gizi yang dikonsumsi ${ }^{11 .}$ Penelitian ini bertujuan untuk mengetahui hubungan antara aktivitas fisik dan asupan gizi dengan status gizi lebih pada anak usia sekolah dasar.

\section{METODE}

Data yang dikumpulkan dalam penelitian ini diperoleh tanpa adanya perlakuan pada subyek penelitian sehingga penelitian ini bersifat observasional analitik. Variabel yang digunakan dalam penelitian ini adalah aktivitas fisik dan asupan gizi. Variabel dependen dalam penelitian ini adalah status gizi lebih responden sedangkan variabel independen penelitian ini adalah asupan gizi dan aktivitas fisik. Penelitian ini termasuk ke dalam penelitian cross-sectional dimana variabel penelitian diperoleh dalam suatu periode tertentu. Penelitian ini dilakukan di SDN Ketabang 1 Kota Surabaya pada bulan November 2017. Penelitian ini telah lolos kaji etik dengan No 589-KEPK.

Populasi penelitian ini adalah seluruh anak SD Ketabang 1 umur 8-12 tahun dengan status gizi lebih sebanyak 120 siswa. Perhitungan besar sampel dalam penelitian ini didapatkan hasil sebanyak 88 sampel dengan menggunakan rumus Lemeshow. Kriteria inklusi dalam penelitian ini adalah siswa usia 8-12 tahun yang mengalami masalah gizi lebih (IMT/U >1 SD), bersedia menjadi responden. Sampel didapatkan dengan menggunakan metode simple random sampling. Pengumpulan meliputi pengukuran berat 
badan dan tinggi badan, wawancara food recall 2×24 jam dan pengukuran aktivitas fisik dengan mengisi kuesioner Physical Activity Questionnaire for Children (PAQ-C). Data kemudian dianalisis dengan uji chi square untuk menganalisis hubungan antara aktivitas fisik dan asupan gizi dengan status gizi lebih.

Angka kecukupan energi untuk anak usia 7-9 tahun adalah sebesar $1850 \mathrm{kkal}$ sedangkan untuk anak usia 10-12 tahun pada laki-laki sebesar 2100 dan pada anak perempuan sebesar 2000 kkal. Angka kecukupan karbohidrat untuk anak usia 7-9 tahun adalah sebesar 245 gram, sedangkan untuk anak usia 10-12 tahun pada laki-laki sebesar 289 gram dan perempuan sebesar 275 gram. Angka kecukupan lemak untuk anak usia 7-9 tahun adalah sebesar 72 gram, sedangkan untuk anak usia 10-12 tahun pada laki-laki sebesar 70 gram dan perempuan sebesar 67 gram. Angka kecukupan protein untuk anak usia 7-9 tahun adalah sebesar 49 gram, sedangkan untuk anak usia 10-12 tahun pada laki-laki sebesar 56 gram dan perempuan sebesar 60 gram. Masukan makanan total ditaksir dari jumlah makanan yang dikonsumsi oleh anak sekolah dasar dalam waktu $2 \times 24$ jam dengan menggunakan metode food recall. Hasil penaksiran makanan diubah dalam satuan gram kemudian dikonversikan dengan program nutrisurvey lalu dibandingkan dengan Estimated Average Recommended (EAR). Pengkategorian untuk energi dan protein adalah dikategorikan cukup apabila $\geq 77 \%$ AKG sedangkan dikategorikan kurang apabila < 77\% AKG. Sedangkan untuk karbohidrat dan lemak dibandingkan dengan Acceptable Macronutrient Distribution Ranges (AMDR) kemudian dikategorikan kurang dari range normal, pada range normal, dan di atas range normal. Range normal untuk karbohidrat adalah 45 - 65\% AKG, kategori kurang dari range untuk karbohidrat apabila < 45\% AKG dan diatas range normal apabila 45\% AKG. Range normal untuk lemak adalah $20-35 \%$ energi dari lemak, kategori kurang dari range untuk lemak apabila < $20 \%$ energi dari lemak dan diatas range normal bila $>35 \%$ energi dari lemak.

Aktivitas fisik dinilai menggunakan instrumen Physical Activity Questionnaire for
Children(PAQ-C). Aktivitas fisik responden dalam penelitian ini kemudian dikelompokkan menjadi 2, yaitu rendah (skor 1-4) dan tinggi (skor $\geq 5$ ). Skor diperoleh dari penilaian berdasarkan lembar kuesioner PAQ-C yang telah diisi responden kemudian dihitung skor masing-masing baru kenudian dikategorikan.

Tabel 1. Distribusi Responden Menurut Umur Di SDN Ketabang 1 Kota Surabaya Tahun 2017

\begin{tabular}{lcc}
\hline $\begin{array}{c}\text { Karakteristik } \\
\text { Responden }\end{array}$ & $\mathbf{n}$ & $\mathbf{\%}$ \\
\hline Umur & & \\
8 Tahun & 1 & 1,1 \\
9 Tahun & 10 & 11,4 \\
10 Tahun & 37 & 42,0 \\
11 Tahun & 32 & 36,4 \\
12 Tahun & 7 & 8,0 \\
Jenis Kelamin & & \\
$\quad$ Laki-Laki & 46 & 52,3 \\
Perempuan & 42 & 47,7 \\
\hline
\end{tabular}

Tabel 2. Distribusi Responden Menurut Status Gizi di SDN Ketabang 1 Kota Surabaya Tahun 2017

\begin{tabular}{lcc}
\hline \multicolumn{1}{c}{ Kategori } & $\mathbf{n}$ & \% \\
\hline Obesitas & 48 & 54,5 \\
Gemuk & 40 & 45,5 \\
\hline
\end{tabular}

\section{HASIL DAN PEMBAHASAN}

\section{Karakteristik Responden}

Karakteristik responden meliputi umur, jenis kelamin dan status gizi di SDN Ketabang 1 Kota Surabaya Tahun 2017. Berdasarkan tabel 1 dapat diketahui bahwa sebagian besar umur reponden adalah berada pada kelompok usia 10 tahun yaitu sebanyak $42 \%$. Sebagian besar responden dalam penelitian ini adalah berjenis kelamin laki-laki yaitu sebanyak $52,3 \%$. Tabel 2 menunjukkan bahwa status gizi responden yang mengalami obesitas yaitu sebesar $54,5 \%$ sedangkan untuk sisanya sebesar $45,5 \%$ berstatus gizi gemuk. Penelitian ini menunjukkan bahwa sebagian besar respondennya sebagian besar berusia 10 tahun mengalami obesitas. Hal ini disebabkan bahwa diusia 8-10 tahun baik siswa laki-laki maupun perempuan mempunyai nafsu makan yang cenderung meningkat sebagai persiapan 
Tabel 3. Hubungan Aktivitas Fisik dengan Status Gizi Lebih di SDN Ketabang 1 Kota Surabaya Tahun 2017

\begin{tabular}{lccccc}
\hline \multirow{2}{*}{ Aktivitas Fisik } & \multicolumn{2}{c}{ Overweight } & \multicolumn{2}{c}{ Obesitas } & \multirow{2}{*}{$\boldsymbol{P}$ value } \\
\cline { 2 - 5 } & $\mathbf{n}$ & $\mathbf{\%}$ & $\mathbf{n}$ & $\mathbf{\%}$ & \\
\hline Rendah & 33 & 82,5 & 29 & 60,4 & \multirow{2}{*}{0,024} \\
Tinggi & 7 & 17,5 & 19 & 39,6 & \\
\hline Total & 40 & 100 & 48 & 100 & \\
\hline
\end{tabular}

Tabel 4. Hubungan Asupan Gizi dengan Status Gizi Lebih di SDN Ketabang 1 Kota Surabaya Tahun 2017

\begin{tabular}{|c|c|c|c|c|c|}
\hline \multirow{3}{*}{$\begin{array}{c}\text { Tingkat } \\
\text { konsumsi energi }\end{array}$} & \multicolumn{4}{|c|}{ Status Gizi } & \multirow{3}{*}{$P$ value } \\
\hline & \multicolumn{2}{|c|}{ Overweight } & \multicolumn{2}{|c|}{ Obesitas } & \\
\hline & $\mathrm{n}$ & $\%$ & $\mathbf{n}$ & $\%$ & \\
\hline Cukup & 35 & 87,5 & 34 & 70,8 & \multirow{3}{*}{0,05} \\
\hline Kurang & 5 & 12,5 & 14 & 29,2 & \\
\hline Total & 40 & 100 & 48 & 100 & \\
\hline \multirow{3}{*}{$\begin{array}{l}\text { Tingkat } \\
\text { konsumsi } \\
\text { protein }\end{array}$} & \multicolumn{4}{|c|}{ Status Gizi } & \multirow{2}{*}{$P$ value } \\
\hline & \multicolumn{2}{|c|}{ Overweight } & \multicolumn{2}{|c|}{ Obesitas } & \\
\hline & $n$ & $\%$ & $\mathbf{n}$ & $\%$ & \multirow{4}{*}{0,048} \\
\hline Cukup & 34 & 85 & 32 & 66,7 & \\
\hline Kurang & 6 & 15 & 16 & 33,3 & \\
\hline Total & 40 & 100 & 48 & 100 & \\
\hline \multirow{3}{*}{$\begin{array}{c}\text { Tingkat } \\
\text { konsumsi } \\
\text { karbohidrat }\end{array}$} & \multicolumn{4}{|c|}{ Status Gizi } & \multirow{2}{*}{$P$ value } \\
\hline & \multicolumn{2}{|c|}{ Overweight } & \multicolumn{2}{|c|}{ Obesitas } & \\
\hline & $n$ & $\%$ & $\mathbf{n}$ & $\%$ & \multirow{5}{*}{0.05} \\
\hline$<$ range normal & 0 & 0 & 0 & 0 & \\
\hline Range normal & 2 & 5 & 9 & 18,7 & \\
\hline$>$ range normal & 38 & 95 & 39 & 81,3 & \\
\hline Total & 40 & 100 & 48 & 100 & \\
\hline \multirow{3}{*}{$\begin{array}{c}\text { Tingkat } \\
\text { konsumsi lemak }\end{array}$} & \multicolumn{4}{|c|}{ Status Gizi } & \\
\hline & \multicolumn{2}{|c|}{ Overweight } & \multicolumn{2}{|c|}{ Obesitas } & $P$ value \\
\hline & $\mathrm{n}$ & $\%$ & $\mathrm{n}$ & $\%$ & \multirow{5}{*}{0,047} \\
\hline$<$ range normal & 0 & 0 & 0 & 0 & \\
\hline Range normal & 19 & 47,5 & 13 & 27 & \\
\hline$>$ range normal & 21 & 52,5 & 35 & 73 & \\
\hline Total & 40 & 100 & 48 & 100 & \\
\hline
\end{tabular}

menuju usia remaja. Dalam hal ini pertumbuhan anak laki-laki cenderung lebih meningkat dibandingkan anak perempuan ${ }^{12}$. Pernyataan tersebut sejalan penelitian lain yang mengungkapkan bahwa anak laki-laki lebih sering mengalami gizi lebih dibandingkan anak perempuan ${ }^{13}$.

\section{Aktivitas Fisik}

Berdasarkan tabel 3 dapat diketahui bahwa sebagian besar aktivitas fisik responden berada dalam kategori rendah. Sebagian besar responden dengan status gizi gemuk mempunyai presentase aktivitas fisik yang rendah sebanyak $82,5 \%$ sedangkan sebagian besar responden dengan status gizi obesitas mempunyai presentase aktivitas fisik yang rendah sebanyak $60.4 \%$. Hasil uji statistik dengan menggunakan uji chi square dengan $\alpha$ $=0,05$ diperoleh nilai $p 0,024$, dimana nilai $p$ lebih kecil dari $\alpha$. Hal ini menunjukkan bahwa 
ada hubungan antara aktivitas fisik dengan status gizi lebih di SDN Ketabang 1 Kota Surabaya tahun 2017.

Hasil penelitian ini senada dengan penelitian yang menyebutkan bahwa anak dengan tingkat aktivitas yang rendah memiliki indeks massa tubuh yang lebih dari nilai normal dan beresiko mengalami masalah gizi lebih ${ }^{14,15}$. Aktivitas fisik dapat mempengaruhi kejadian gizi lebih pada anak. Hal ini dikarenakan ketidakseimbangan antara intake energi yang dimasukkan ke dalam tubuh dengan energi yang dikeluarkan dari tubuh ${ }^{16}$.

Gaya hidup yang berubah menyebabkan terjadinya perubahan pula pada pola makan yang tinggi kalori, lemak dan kolesterol yang sayangnya tidak diimbangi dengan aktivitas fisik sehingga akan menimbulkan masalah gizi lebih. Pola makan dengan tinggi kalori, lemak dan kolesterol tersebut haruslah diimbangi dengan aktivitas fisik agar terjadi keseimbangan asupan gizi. Keaktifan anak dalam melakukan aktivitas fisik akan mempengaruhi indeks massa tubuhnya sehingga akan berdampak pada kurangnya resiko timbulnya masalah gizi lebih. Hal ini dikarenakan adanya keseimbangan antara asupan yang dimakan dengan asupan yang dikeluarkan. Manfaat dari aktivitas fisik ini adalah dapat berkurangnya massa lemak tubuh dan meningkatkan kekuatan otot sehingga dapat mencegah penimbunan lemak yang berlebihan didalam tubuh $^{17}$. Aktivitas fisik merupakan kegiatan sehari hari yang dilakukan selama 7 hari dengan dihitung menggunakan durasi menit. Menurut hasil penelitian pengkategorian aktivitas fisik ini adalah apabila melakukan kegiatan < 45 menit/hari tergolong dalam aktivitas sedang hingga berat, dan bila melakukan aktivitas fisik selama $\geq 45$ menit/ hari tergolong sebagai aktivitas fisik yang tinggi ${ }^{18}$.

Pada penelitian ini didominasi oleh rendahnya aktivitas fisik yang dilakukan responden. Hal ini dikarenakan sebagian besar dari responden melakukan aktivitas fisik yang diselenggarakan oleh sekolah setiap satu minggu sekali yaitu pada saat jam pelajaran olahraga. Waktu istirahat dimanfaatkan oleh responden untuk membeli jajanan yang tersedia didalam maupun diluar sekolah.
Selain itu mereka menghabiskan waktu istirahat dengan bercengkrama dengan sesama teman didalam kelas. Diluar jam sekolah sebagian besar responden menghabiskan waktu dengan menonton televisi, bermain game maupun belajar. Hal ini sejalan dengan penelitian yang menyatakan bahwa Adanya peningkatan prevalensi obesitas yang terjadi pada anak sekolah ini disebabkan oleh salah satunya bahwa anak lebih cenderung menghasbiskan waktu luangnya untuk menonton televisi dan kegiatan lain yang tidak mengeluarkan energi ${ }^{19}$. Hal inilah yang menyebabkan aktivitas fisik mereka tergolong rendah sehingga berdampak pada keseimbangan asupan makanan yang mereka konsumsi.

\section{ASUPAN GIZI}

Tabel 4 dapat diketahui bahwa asupan energi sebagian besar responden dengan status gizi gemuk berada pada kategori cukup yaitu sebesar $87,5 \%$ dan sebagian besar responden dengan status gizi obesitas pun berada pada kategori cukup yaitu sebesar $70,8 \%$. Asupan protein sebagian besar responden dengan status gizi gemuk berada pada kategori cukup yaitu sebesar $85 \%$ dan sebagian besar responden dengan status gizi obesitas berada pada kategori cukup sebesar $66,7 \%$. Asupan karbohidrat sebagian besar untuk responden dengan status gizi gemuk berada pada range diatas normal sebesar $95 \%$ dan sebagian besar responden dengan status gizi obesitas juga berada pada kategori range diatas normal yaitu sebesar $81,3 \%$. Asupan lemak sebagian besar responden dengan status gizi gemuk berada pada range diatas normal yaitu sebesar $52,3 \%$ dan sebagian besar responden dengan status gizi obesitas juga berada pada kategori range diatas normal yaitu sebesar $73 \%$.

Hasil uji statistik menggunakan uji chi square dengan $\alpha=0,05$ diperoleh nilai $p$ secara berturut-turut untuk asupan energi, protein, karbohidrat dan lemak adalah 0,05; 0,048; 0,05; dan 0,047. Hal ini menunjukkan bahwa nilai $\mathrm{p}<0,05$ sehingga dapat disimpulkan bahwa adanya hubungan antara asupan gizi dengan status gizi lebih pada anak di SDN Ketabang 1 Kota Surabaya tahun 2017. 
Hasil penelitian ini serupa dengan penelitian yang menyatakan bahwa adanya hubungan antara asupan energid an zat gizi makro dengan status gizi ${ }^{20}$. Ketidakseimbangan pola konsumsi mengakibatkan kurangnya maupun lebihnya zat gizi yang masuk dalam tubuh. Hal ini ditambah dengan kebiasaan anak yang lebih menyukai jajan dan dapat memilih jajanan yang mereka sukai. Jenis jajanan yang kebanyakan dikonsumsi anak-anak adalah jenis jajanan yang banyak mengandung lemak dan energi ${ }^{8}$. Asupan energi yang cukup tinggi dari asupan makanan maka akan disimpan sebagai lemak oleh tubuh. Asupan tinggi energi dan lemak ini akan menyebabkan peningkatan berat badan pada anak. Beberapa penelitian menyebutkan bahwa adanya hubungan antara asupan energi dengan kejadian obesitas. Hal ini sejalan dengan penelitian yang menyebutkan bahwa adanya hubungan antara asupan energi dengan kejadian obesitas ${ }^{21,22}$.

Kecukupan asupan protein nabati adalah $60-80 \%$ kebutuhan protein sedangkan kecukupan asupan hewani adalah 20-40\% kebutuhan protein. Tubuh manusia tidak dapat menampung kelebihan protein, sehingga akan di simpan dalam bentuk trigliserida oleh tubuh. Hal inilah yang menyebabkan kenaikan jaringan lemak sehingga menyebabkan kegemukan ${ }^{23}$. Protein sangatlah penting dan dibutuhkan pada masa pertumbuhan terutama bagi anak usia sekolah. Namun kelebihan protein dapat mengakibatkan kelebihan berat badan pada seseorang. Apabila terjadi kelebihan protein maka akan disimpan sebagai lemak ${ }^{24}$. Hal ini juga disampaikan beberapa penelitan yang menyebutkan bahwa kelebihan asupan protein didalam tubuh maka akan disimpan sebagai lemak ${ }^{25,26}$. Lemak merupakan salah satu zat gizi makro yang merupakan sumber energi bagi tubuh seperti halnya protein. Lemak yang berlebihan akan menyebabkan timbulnya resiko masalah gizi lebih. Makanan yang mengandung lemak biasaya akan terasa lezat dengan tingkat kekenyangan yang rendah sehingga membuat seseorang untuk mengkonsumsinya secara terus menerus. Penyimpanan lemak mempunyai kapasitas yang tidak terbatas. Kelebihan lemak yang tidak diiringi dengan oksidasi lemak dapat menyebabkan 96\% lemak disimpan dalam tubuh $^{27}$. Karbohidrat berperan vital sebagai pemelihara kesehatan fungsi usus selain sebagai sumber karbohidrat. Konsumsi karbohidrat hendaknya diberikan selang waktu tertentu, hal ini bertujuan agar tubuh selalu memperoleh glukosa untuk keperluan energi karena persediaan glikogen hanya bertahan untuk keperluan beberapa jam. Apabila konsumsi karbohidrat berlebih maka akan diubah menjadi lemak di dalam hati ${ }^{24}$.

\section{KESIMPULAN}

Berdasarkan hasil penelitian dapat disimpulkan bila terdapat hubungan asupan gizi dan aktvitas fisik dengan gizi lebih pada anak usia sekolah dasar di Sekolah Dasar Negeri Ketabang 1 Kota Surabaya. Disarankan untuk responden penelitian agar lebih memperbanyak aktivitas fisik yaitu dengan olahraga agar terjadi keseimbang antara kalori yang masuk dengan kalori yang dipergunakan untuk aktivitas serta memperbanyak konsumsi makan buah dan sayur untuk keseimbangan gizi.

Keterbatasan penelitian ini adalah belum dianalisis secara lebih lanjut tentang apakah ada perbedaan antara responden dengan status gizi gemuk dan obesitas terhadap setiap variabel independen. Penelitian ini hanya menganalisis hubungan antara status gizi lebih dengan variabel independennya.

\section{ACKNOWLEDGEMENT}

Peneliti mengucapakan terimakasih kepada SDN Ketabang 1 Kota Surabaya yang telah memberikan izin sehingga penelitian ini dapat terlaksana, siswa-siswa yang menjadi responden pada penelitian ini, serta temanteman yang telah membantu dalam penelitian ini.

\section{REFERENSI}

1. Permatasari, I.R.I., Mayulu, N., Hamel, R. Analisa Riwayat Orang Tua sebagai Faktor 
Resiko Obesitas pada Anak SD di Kota Manado. Ejournal Keperawatan 1, 1-7 (2013).

2. WHO. Global prevalence and trends of overweight and obesity among preschool children. WHO (2011).

3. de Onis, M., Blössner, M. \& Borghi, E. Global prevalence and trends of overweight and obesity among preschool children. Am. J. Clin. Nutr. 92, 1257-1264 (2010).

4. Sartika, R. A. . Faktor Risiko Obesitas pada Anak 5-15 Tahun di Indonesia. Makara, Kesehat. 15, 37-43 (2011).

5. Badan Penelitian dan Pengembangan Kesehatan. Riset Kesehatan Dasar (RISKESDAS) 2013. Lap. Nas. 2013 1-384 (2013). doi:1 Desember 2013

6. Departemen Kesehatan RI. Obesitas dan Kurangnya Aktivitas Fisik Menyumbang 30\% Kanker. 18 Februari 2009 (2009). Available at: http://www.kemkes.go.id/development/ site/jkn/index.php?cid=137\&id=obesitasdan-kurang-aktivitas-fisik-menyumbang30\%25-kanker.html.

7. Anggraeni, A. . Hubungan Pola Konsumsi Buah dan Sayur Dengan Risiko Obesitas Pada Anak Usia Sekolah Di SDN Ketabang 1 Surabaya. (Universitas Airlangga, 2016).

8. Utomo, G. T., Junaidi, S. \& Rahayu, S. Latihan Senam Aerobik Untuk Menurunkan Berat Badan, Lemak dan Kolesterol. J. Sport. Sci. Fit. 1, 6-10 (2012).

9. Yaqin, M.K., Nurhayati, F. Prevalensi Obesitas Pada Anak Usia Sd Menurut Imt/U Di Sd Negeri Ploso li No 173 Surabaya. J. Pendidik. Olahraga dan Kesehat. 2, 114-118 (2014).

10. D'Addesa, D. et al. Dietary Intake and Physical Activity of Normal Weight and Overweight/Obese Adolescents. Int. J. Pediatr. 2010, 1-9 (2010).

11. Pramono, A., Sulchan, M. Kontribusi Makanan Jajan Dan Aktivitas Fisik Terhadap Kejadian Obesitas Pada Remaja Di Kota Semarang. Gizi Indones. 37, 129136 (2014).

12. Bidjuni, H., Rompas, S. \& Bambuena, M. . Hubungan Pola Makan Dengan Kejadian
Obesitas Pada Anak Usia 8-10 Tahun Di Sd Katolik 03 Frater Don Bosco Manado. J. Keperawatan 2, 1-7 (2014).

13. Ogden, C. L., Carroll, M. D., Kit, B. K. \& Flegal, M. Prevalence of Childhood and Adult Obesity in the United States, 20112012. Jama 311, 806-814 (2016).

14. Lisbeth, N. Hubungan Kejadian Obesitas paada Anak dengan Kebiasaan Mengkonsumsi Makanan Siap Saji di SDIT Ulul Albab Bekasi Tahun 2013. J. Ilm. Keperawatan STIKes Med. Cikarang 4, (2014).

15. Octari, C., Liputo, N. I. \& Edison. Hubungan Status Sosial Ekonomi dan Gaya Hidup dengan Kejadian Obesitas pada Siswa SD Negeri 08 Alang Lawas Padang. J. Kesehat. Andalas 3, 131-135 (2014).

16. Colley, R. C. et al. Physical activity and sedentary behavior during the early years in Canada: a cross-sectional study. Int. J. Behav. Nutr. Phys. Act. 10, 54 (2013).

17. Salbe, A. D. et al. Relation between physical activity and obesity. Am. J. Clin. Nutr. 78, 193-194 (2003).

18. Farpour-Lambert, N. J. et al. Physical Activity Reduces Systemic Blood Pressure and Improves Early Markers of Atherosclerosis in Pre-Pubertal Obese Children. J. Am. Coll. Cardiol. 54, 23962406 (2009).

19. Carson, V., Iannotti, R. J., Pickett, W. \& Janssen, I. Urban and rural differences in sedentary behavior among American and Canadian youth. Health Place 17, 920928 (2011).

20. Restuastuti, T., Jihadi, M. \& Ernalia, Y. Hubungan Pola Makan dan Aktivitas Fisik terhadap Obesitas pada Remaja di SMA Negeri 5 Pekanbaru. J. Online Mhs. Fak. Kedokt. Univ. Riau 3, 1-20 (2016).

21. Wulandari, N. W. M., Muniroh, L. \& Nindya, T. S. Asupan Energi Dan Aktivitas Fisik Berhubungan Dengan Z-Score IMT/U Anak Sekolah Dasar di Daerah Perdesaan. Media Gizi Indones. 10, 51-56 (2015).

22. Maidelwita, Y. Pengaruh Faktor Genetik, Pola Konsumsi dan Aktivitas Fisik dengan Kejadian Obesitas pada Anak Kelas 4-6 SD SBI Percobaan Ujung Gurun Padang. J. 
Mercubaktijaya 1-12 (2012).

23. Suryandari, B. D. \& Widyastuti, N. Hubungan Asupan Protein Dengan Obesitas Pada Remaja. J. Nutr. Collage 4, 492-498 (2015).

24. Almatsier, S. Prinsip Dasar Ilmu Gizi. (PT Gramedia Pustaka Utama, 2009).

25. Sasmito, P. . Hubungan Asupan Zat Gizi Makro ( Karbohidrat, Protein , Lemak ) Dengan Kejadian Obesitas Pada Remaja Umur 13- 15 Tahun Di Propinsi Dki
Jakarta ( Analisis Data Sekunder Riskesdas 2010 ). Nutr. Diaita 7, 16-23 (2015).

26. Mestuti, K. \& Fitranti, D. . Faktor Risiko Kejadian Overweight Pada Anak Stunting Usia Sekolah Dasar Di Semarang Timur. J. Nutr. Coll. 3, 134-141 (2014).

27. Dewi, PLP., Kartini, A. Hubungan Pengetahuan Gizi, Aktivitas Fisik, Asupan Energi Dan Asupan Lemak Dengan Kejadian Obesitas Pada Remaja Sekolah Menengah Pertama. J. Nutr. Collage 6, 257-261 (2017). 